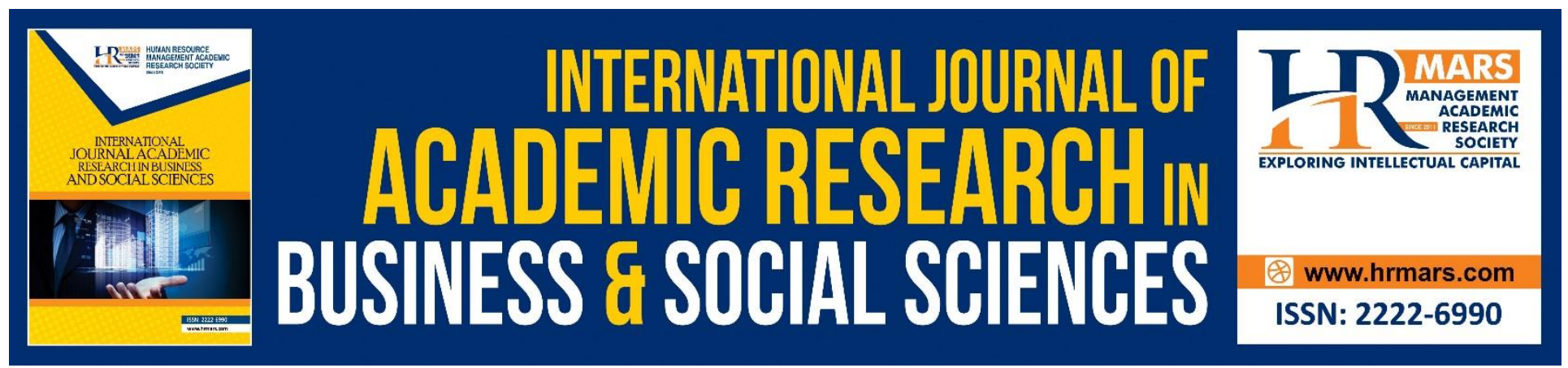

\title{
Experiences of using Authentic Assessment with English Language Young Learners
}

Muhammad Noor Abdul Aziz, Nurahimah Mohd Yusoff

To Link this Article: http://dx.doi.org/10.6007/IJARBSS/v8-i9/4599

DOI: $\quad 10.6007 /$ IJARBSS/v8-i9/4599

Received: 09 August 2018, Revised: 02 September 2018, Accepted: 29 Sept 2018

Published Online: 15 October 2018

In-Text Citation: (Aziz \& Yusoff, 2018)

To Cite this Article: Aziz, M. N. A., \& Yusoff, N. M. (2018). Experiences of using Authentic Assessment with English Language Young Learners. International Journal of Academic Research in Business and Social Sciences, 8(9), $375-384$.

Copyright: @ 2018 The Author(s)

Published by Human Resource Management Academic Research Society (www.hrmars.com)

This article is published under the Creative Commons Attribution (CC BY 4.0) license. Anyone may reproduce, distribute, translate and create derivative works of this article (for both commercial and non-commercial purposes), subject to full attribution to the original publication and authors. The full terms of this license may be seen

at: http://creativecommons.org/licences/by/4.0/legalcode

Vol. 8, No. 9, September 2018, Pg. 375 - 384

http://hrmars.com/index.php/pages/detail/IJARBSS

JOURNAL HOMEPAGE

Full Terms \& Conditions of access and use can be found at http://hrmars.com/index.php/pages/detail/publication-ethics 


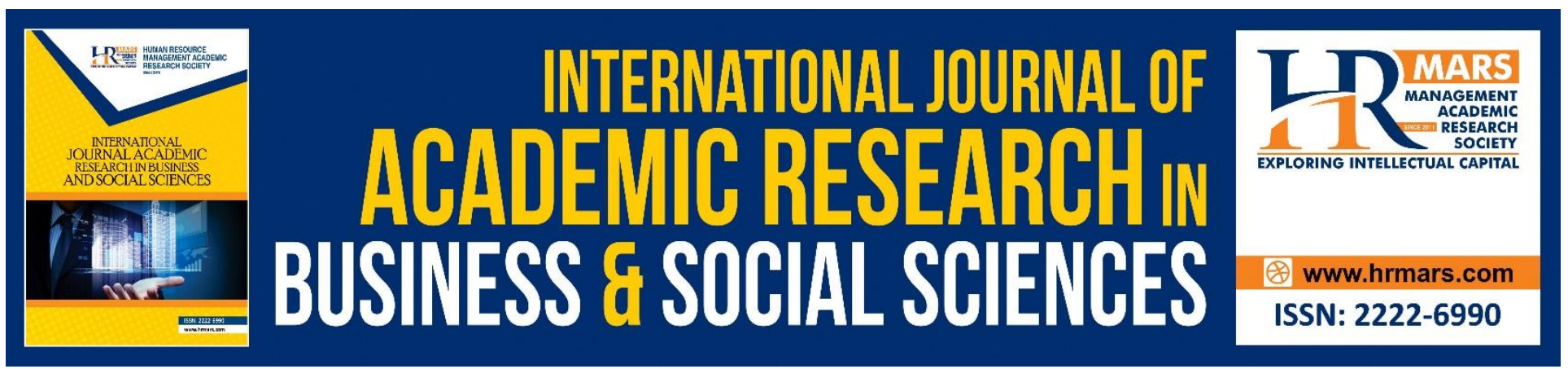

\title{
Experiences of using Authentic Assessment with English Language Young Learners
}

\author{
Muhammad Noor Abdul Aziz \\ Awang Had Salleh Graduate School of Arts and Science (AHSGS), College of Arts and Sciences, \\ Universiti Utara Malaysia, UUM Sintok, Kedah Darul Aman, Malaysia. \\ Prof. Dr. Nurahimah Mohd Yusoff \\ Awang Had Salleh Graduate School of Arts and Science (AHSGS), College of Arts and Sciences, \\ Universiti Utara Malaysia, UUM Sintok, Kedah Darul Aman, MALAYSIA.
}

\begin{abstract}
This paper brings about the discussion on findings from an interview with young learners about school-based assessment that takes place in their English language classroom. Their ideas, comments and feelings were recorded and analysed. Literature has pointed out that including learners' views in learning as well as in assessment will yield better learning outcomes. The discussion will be touching on what the young learners' think about the 'new' assessment that takes place in the classroom and how they want it to be carried out. The results of the study show that there are five emerging themes: a) lack of young learners' involvement in assessment, b) lack of support from the school administration, c) overwhelming documentation d) need for inclusion of parental involvement, and e) presence of self and peer assessments. Insights from the findings can be an eye-opener for the teachers to carry out improved authentic assessment practices in their classrooms in tandem with the ministry's aspiration to provide formative feedback that places student learning at centre.

Keywords: Authentic Assessment, School-Based Assessment, English Language Teaching, Young Learners, Qualitative Case Study

\section{INTRODUCTION}

Young learners can be defined as children of 5 to 12 years of old (Hazita, 2012). They learn English from pre-school up to secondary school and English is considered as one of the core subjects in schools.

As much as the English Language for young learners is concerned, there have been numerous changes and improvements that have taken place for the betterment of teaching, learning and assessment (Tajularipin, Ahmad Fauzi \& Suriati, 2015). School-based assessment (SBA) is one of the recent changes in assessment and has been implemented in schools commencing 2010.
\end{abstract}


INTERNATIONAL JOURNAL OF ACADEMIC RESEARCH IN BUSINESS AND SOCIAL SCIENCES

Vol. 8, No. 9, Sept. 2018, E-ISSN: 2222-6990 @ 2018 HRMARS

SBA has been greatly discussed in the literature (Begum \& Farooqui, 2008; Mansor, Hee Leng, Sattar Rasull, Amnah Raof \& Yusoff, 2013; Hasnida \& Ghazali, 2016). SBA can be considered as a reform in the education as to move away from standardised testing issues. Many countries, namely Australia, Hong Kong and England have made a positive move to adopt SBA as their assessment practice in order to yield better learning outcome of their learners, especially young learners (Malakolunthu \& Hoon, 2010).

In Malaysian context, SBA was incorporated as part of assessment dated back in 2010 when the Ministry of Education introduced the new curriculum which was called Standard Curriculum for Primary School (KSSR) (Norazilawati, Noorzeliana, Mohd Sahandri \& Saniah, 2015). Since then, a myriad of studies on SBA (Faizah, 2011; Muhammad Noor \& Nurahimah, 2015; Mok, Nur Filza, Nor Syazwani \& Siti Suraya, 2016) has been blossoming in Malaysia ranging from the question on its implementation to its effectiveness. There is a variation of SBA that is highlighted in the literature and one of the most recent ones is the Authentic Assessment (AA) (Fatimah, 2014).

SBA is a move to bring a more holistic assessment in schools in accordance with the national philosophy of education that accentuates on "developing the potential of individuals in a holistic and integrated manner, so as to produce individuals who are intellectually, spiritually, emotionally and physically balanced and harmonious" (Ministry of Education Malaysia, 2008, p.ix). Since the current education system in Malaysia is very much exam-oriented (Karpudewan, Roth, \& Abdullah, 2015) and there should arise a focus on other forms of assessment (Azmanirah, Nurfirdawati, Marina, \& Jamil, 2014), there is a need to carry out research to highlight the importance of SBA.

There is a variety of SBA that is being used in schools such as oral assessment, portfolio assessment and authentic assessment which fall under the umbrella of assessment for learning (Swaffield, 2011). Authentic assessment can be defined as "engaging and worthy problems or questions of importance, in which students must use knowledge to fashion performances effectively and creatively" (Wiggins, 1993, p.229). He further added that authentic assessment involves tasks of replicas of problems faced by adults in the real setting. Learners will have to apply knowledge and skills in real world environment (Waugh \& Gronlund, 2013) for instance interviewing the community for input on recycling.

In authentic assessment, teacher's role is as a facilitator and learners play an integral part in learning (Azim \& Khan, 2012). However, this is not the case in Malaysian education system. Most classes remain teacher-centred (Yin Peen \& Yusof Arshad, 2014). As such, this paper aspires to fill in the gap and highlight the voices of young learners which can be taken into consideration by the teachers in preparing and carrying out systematic as well as effective assessment with them.

Since authentic assessment puts much emphasis on the learner, it is apt that learners' views and trepidations are explored. Frey (2013) highlighted that in authentic assessment the learners should know and be aware of the constructs. In addition to that, Frey also asserted that the learners should be given an opportunity to defend their work with substantial justification. Even though this is a concern in authentic assessment, many teachers tend to control the classroom learning by preparing a mould for what is to be learnt by the learner causing a lack in critical thinking (Azmanirah et al., 2014). Studies have been carried out in the past to elicit views about classroom assessment from 
INTERNATIONAL JOURNAL OF ACADEMIC RESEARCH IN BUSINESS AND SOCIAL SCIENCES

Vol. 8, No. 9, Sept. 2018, E-ISSN: 2222-6990 ㄷ 2018 HRMARS

secondary school students only (Suzana \& Jamil, 2012; Yin \& Adamson, 2015). However, as much as young learners are concerned, there are very limited studies probing to hear their voice (Little, 2005). This invites the researchers to seek the views of young learners on the assessment that takes place in the classroom.

\section{AIMS OF THE STUDY}

This study is guided by two main research questions which are:

1. How do the students feel about authentic assessment in their classroom?

2. What are their concerns and ideas for a better assessment practice in their classroom?

\section{METHODOLOGY}

This research explored the voices of 15 young learners in a year 5 class of a Malaysian primary school regarding the use of authentic assessment by their English Language teacher. Their excitement as well as concerns and ideas were recorded and analysed. In this qualitative case study, the young learners were interviewed with a set of protocols without the presence of their teacher to avoid bias (Creswell, 2008) and to establish a friendly environment with them.

Their school was chosen for the study for the reason that their teacher was an excellent teacher who was awarded by the ministry and she has been practising SBA since its establishment which was evident in her teaching portfolio. A semi-structured focus group interview (Ritchie \& Lewis, 2003; Creswell, 2008) was carried out with the children with 10 main questions asked in their native language which was Malay language to maintain the validity and reliability of the interview. The children's consent along with their teacher's was obtained and the interview guidelines were elaborated in simple language to the children. A series of observation was also carried out in their classroom and the teacher's teaching documents were simultaneously observed to triangulate what the children said about the practice of authentic assessment in their classroom. Their honest responses were typed and transcribed, translated into English with proofreading done by an expert, before they were analysed by the researchers and categorised into the emerging themes from the key words.

The young learners chosen in this study are those who were present in the class on the day of the interview. There were 28 of them in the class but only 15 were present. The others were absent because they were tired after sports day rehearsal the day before. Table 1 summarises the profile of the young learners involved in this study. Pseudonyms were used in this profile to maintain confidentiality (Braun \& Clarke, 2013). 
INTERNATIONAL JOURNAL OF ACADEMIC RESEARCH IN BUSINESS AND SOCIAL SCIENCES

Vol. 8, No. 9, Sept. 2018, E-ISSN: 2222-6990 @ 2018 HRMARS

Table 1

Profile of the participants

\begin{tabular}{|c|c|c|c|}
\hline No. & $\begin{array}{l}\text { Pupils' } \\
\text { names }\end{array}$ & Profile & $\begin{array}{l}\text { Positions in } \\
\text { school }\end{array}$ \\
\hline 1. & Lia & $\begin{array}{l}\text { A petite girl but with a strong command of } \\
\text { the English language. Answered all the } \\
\text { questions posed well with examples of } \\
\text { incidents. }\end{array}$ & School prefect \\
\hline 2. & Zara & $\begin{array}{l}\text { Soft-spoken but intelligent. She won all the } \\
\text { grammar quizzes in class. }\end{array}$ & $\begin{array}{l}\text { Secretary of the } \\
\text { English Language } \\
\text { society }\end{array}$ \\
\hline 3. & Fisha & $\begin{array}{l}\text { The talkative one in the class. She is lways } \\
\text { being reprimanded for chatting all the way } \\
\text { when the teacher was teaching. }\end{array}$ & $\begin{array}{l}\text { Assistant class } \\
\text { monitor }\end{array}$ \\
\hline 4. & Siti & $\begin{array}{l}\text { Has been very eager to participate in this } \\
\text { study from Day } 1 \text { because her mother was } \\
\text { also doing a research currently. }\end{array}$ & Pupil in the class \\
\hline 5. & Nabilah & $\begin{array}{l}\text { Very strict with her friends. Does not tolerate } \\
\text { jokes and funny stories. Always submits work } \\
\text { on time. }\end{array}$ & Pupil in the class \\
\hline 6. & Hwa & $\begin{array}{l}\text { Best friends with Lia. Very proficient in the } \\
\text { English Language. }\end{array}$ & School prefect \\
\hline 7. & Sithra & $\begin{array}{l}\text { The only Indian girl in the class. Speaks fluent } \\
\text { Malay Language but average in English. }\end{array}$ & School librarian \\
\hline 8. & Joseph & $\begin{array}{l}\text { The best pupil in the class but very quiet. Only } \\
\text { talks when he is talked to. }\end{array}$ & School prefect \\
\hline 9. & Abdullah & $\begin{array}{l}\text { A sociable boy who never failed to greet } \\
\text { teachers with his amiable smile. }\end{array}$ & Pupil in the class \\
\hline 10. & Adib & $\begin{array}{l}\text { A lecturer's son. Has good command of the } \\
\text { English language. Loved the interview session } \\
\text { and responded well. }\end{array}$ & School librarian \\
\hline 11. & Rajen & $\begin{array}{l}\text { Good friends with Luthfi. He spoke in English } \\
\text { but Luthfi answered in Malay. }\end{array}$ & Pupil in the class \\
\hline 12. & Kamal & $\begin{array}{l}\text { An avid reader. Held a storybook all the time. } \\
\text { Fluent in English and Malay. }\end{array}$ & Pupil in the class \\
\hline 13. & Zainal & $\begin{array}{l}\text { Very quiet and quite poor in the English } \\
\text { language. Had to slow down when asking him } \\
\text { questions. He needed probing a lot. }\end{array}$ & Pupil in the class \\
\hline 14. & Aliff & $\begin{array}{l}\text { The joker of the class. Always cheerful. } \\
\text { Average in the class. }\end{array}$ & Pupil in the class \\
\hline 15. & Wee Vern & $\begin{array}{l}\text { Very pleasant in attitude. Respected and } \\
\text { loved by his classmates. }\end{array}$ & Class monitor \\
\hline
\end{tabular}

\section{RESULTS AND DISCUSSION}

Thematic analysis was carried out during analysis of data as it assures flexibility and captures key ideas of the descriptive account (Braun \& Clarke, 2013). The researchers read, transcribed and identified preliminary ideas while generating codes. Later, they searched for the primary themes by collating the codes. They also reviewed the themes before defining and arriving at distinctive definitions.

The analysis of data congregated from the interviews and classroom observations produced five emergent themes. They were (1) lack of young learners' involvement in assessment (2) lack of support 
INTERNATIONAL JOURNAL OF ACADEMIC RESEARCH IN BUSINESS AND SOCIAL SCIENCES

Vol. 8, No. 9, Sept. 2018, E-ISSN: 2222-6990 (C) 2018 HRMARS

from the school administration (3) overwhelming documentation (4) need for inclusion of parental involvement in the assessment and (5) self-assessment and peer assessment.

1) Lack of young learners' involvement in assessment

It is evident that the children were not involved in the decision on assessment. The teacher prepared her own assessment plans and carried them out tentatively. She referred to the relevant documents supplied by the ministry for assessment purposes and worked with them. In her lesson notes, she regularly wrote:

"Pupils progress recorded in the transit record."

(Lesson Note, $16^{\text {th }}$ Nov/18 $18^{\text {th }}$ Nov)

When the researchers studied the transit record, there were only ticks with date of achievement on certain descriptors based on the syllabus. The children argued that they were not informed on the days of assessment:

"I don't know when teacher ticks the transit record." (Adib)

"Our teacher does not tell when she wants to assess. We only know exam dates." (Lia)

The young learners mentioned that they assessed their friends' presentation but with strict monitoring from the teacher which made them feel incompetent.

"I feel that Madam N does not trust us. She keeps asking us if we are sure of the score we gave to our friends when they presented their project." (Fisha)

"I liked it when we had to assess our friends but we were asked to do it twice for each group because Madam N was not happy with the score we gave." (Rajen)

2) Lack of support from the school administration

It was quite surprising to hear the young learners talk about the school administration. They highlighted that their teacher always mentioned that the school did not allow pupils to do assessment on their own:

"She once said that our HM does not like students doing different assessments other than

tests and exams. I am getting bored with tests. It makes me tired because I have to stay up late at night to study." (Sithra)

"I love SBA because it is not about test. It is about projects and fun learning but our HM does

not care much on the projects we do. In the end, we throw everything away." (Nabilah)

During classroom observation, it can be concluded that the teacher did carry out SBA activities but she did not give feedback on the projects they do, resulting in the learners' not knowing of their strengths and weaknesses.

3) Overwhelming documentation

It is a pity that this excellent teacher focused more on the documentation part. She always seemed to be writing something on her lesson notes and her teaching portfolio was always updated. She had plenty of documents ranging from her lesson notes to pictures of classroom activities and countless reports of what she has done in her classroom.

"Madam N keeps all her files updated. She checks them daily and makes sure new letter are recorded and kept in the file. She brings her teaching portfolio daily to school. She also takes photographs of the children working on tasks."

(Observation Note 4, 20 ${ }^{\text {th }}$ Nov) The researchers felt that she was busy with her documentation and failing to get her learners' responses on what they loved to do in her class even though her classes were all fun and lively. She 
INTERNATIONAL JOURNAL OF ACADEMIC RESEARCH IN BUSINESS AND SOCIAL SCIENCES

Vol. 8, No. 9, Sept. 2018, E-ISSN: 2222-6990 (C) 2018 HRMARS

may have underestimated the children's potential and brushed away their capabilities in giving ideas for better classroom activities.

\section{4) Need for inclusion of parental involvement}

This is an interesting finding from the interview with the young learners. They agreed with one another that their parents should be included in the picture because most of their projects and classroom tasks were completed at home under the supervision of their respective parents:

"My mother usually guides me through the scrapbook project. She did not give me answers but she suggested where I can get information. So, I think Madam N should ask my mother to assess my work also because she sees me doing the project." (Siti)

"I think Madam N should give my parents the assessment form to fill up for the poster I drew at home. They really saw me doing it. Madam $\mathrm{N}$ did not see it." (Adib)

"Madam N once said she would call my dad to see if I did the work by myself. But she didn't." (Zara)

\section{5) Self-assessment and peer assessment}

The young learners feel that self-assessment helps them in writing better English. Their teacher has done journal writing a few times and it improves their English Language.

"I like to write journal. I can tell what I like and what I hate about the activity. I feel that my English is improving." (Zara)

"Madam N always asks us to write journals. At first I find it difficult but now I see that I can write what I think. It makes me feel good." (Hwa)

Peer assessment makes the young learners feel fun and less stressful. They said that they friends' comments are different from what their teacher would say. They also pointed out that guidelines should be given to the learners before peer assessment is allowed.

"Usually I ask my best friend on how I faired in the project I did. He always said that I am good in drawing and I think he is right." (Abdullah)

"I feel happy when my friends say, 'Good job, bro'." (Kamal)

"Our friends should be asked to assess our work but they must be reminded to be fair." (Zainal)

The researchers' observation also matched what was said by the children.

"The children look very happy. The class is filled with laughter and they even cheer 'Yahoo' when the teacher gives them the assessment form to assess their friends' presentation." (Observation Note $4,20^{\text {th }}$ Nov)

From the analysis, it is clear that the young learners are yearning to be a part of the assessment that takes place in the classroom. Literature (Czerniawski \& Kidd, 2011; Segers \& Dochy, 2001) suggests that self-assessment and peer assessment are a fragment of SBA and are great tools to yield better and meaningful results of learning that takes place in the classroom. Teachers should allow young learners to contribute ideas for their own learning and assessment as it is one of the $21^{\text {st }}$ century learning skills which inspires learning autonomy. Yin and Adamson (2015) suggest that when learners are given the priority to choose and make decision about their learning, better learning outcome can be achieved.

It is worth mentioning that a variety of assessment in the SBA is also desired by learners. They approve that learning becomes fun and less stressful when the teacher adopts multiple method of assessment in SBA as opposed to the traditional way assessing. This finding confirms the study by 
INTERNATIONAL JOURNAL OF ACADEMIC RESEARCH IN BUSINESS AND SOCIAL SCIENCES

Vol. 8, No. 9, Sept. 2018, E-ISSN: 2222-6990 @ 2018 HRMARS

(Suzana \& Jamil, 2012) who concluded that various formative assessment technique improved learners' attitude on assessment.

\section{CONTRIBUTION OF THIS STUDY}

This study has sought to shed some light in the use of authentic assessment with young learners in English language classrooms. This is an important move to start school-based assessment (Malakolunthu \& Hoon, 2010) in the classroom as to support the aim and aspiration of the ministry. Apart from that, young learners' motivation will also be boosted with the use of authentic assessment as opposed to standardized testing which is said to 'kill' their interest if rewards and sanctions are not put along with their performance in a test (Amerin \& Berliner, 2003).

\section{IMPLICATIONS AND CONCLUSION}

The study seeks to highlight how young learners feel about authentic assessment and what can be done to improve assessment practices in the classroom. It is apparent that young learners wish to be included in the assessment made by their teachers. They feel that they do have a say in their learning because they are the ones benefitting from the learning in the classroom. The children believe that when their teacher asks their opinion for the next assessment, they are overjoyed and will give creative measures to be taken into consideration.

In relation to that, young learners still respect their teacher's decision despite being given the empowerment to choose topics for their assessment. They also unanimously agree that what their teacher grades is the best for them.

Another major implication from the study is the inclusion of parents in the learning and assessment. This may be a new scenario in Malaysia but it has been practised in other parts of the world for a period of time. It is timely that we introduce some assessment strategies with proper guidance for parents to play their role in the betterment of their children's learning.

It is timely that we move along with $21^{\text {st }}$ century learning paradigm that puts learner at the centre of learning. Authentic assessment can be made more learner-centred with the inclusion of paragogy techniques which allow effective peer learning and peer feedback among students (Corneli \& Danoff, 2011). This will also improve their Higher Order Thinking Skills (HOTS) which is now a prominent educational issue in Malaysian classrooms (Othman \& Mohamad, 2014).

By taking care of their needs, learning can be enhanced and better opportunities and experiences can be produced for the learners. Since the learning of young learners is a concern here, why isn't some empowerment given for them to be accountable for their own learning?

Corresponding Author:

Mr. Muhammad Noor Abdul Aziz

Awang Had Salleh Graduate School of Arts and Science (AHSGS), College of Arts and Sciences, Universiti Utara Malaysia, 06010 UUM Sintok, Kedah Darul Aman, MALAYSIA.

Email: muhammadnoorabdulaziz@gmail.com

\section{REFERENCES}

Amerin, A. L., \& Berliner, D. C. (2003). The effects of high-stakes testing on student motivation and learning. Educational Leadership.

Azim, S., \& Khan, M. (2012). Authentic assessment: An instructional tool to enhance students learning. Academic Research International, 2(3), 314-320. Retrieved from 
INTERNATIONAL JOURNAL OF ACADEMIC RESEARCH IN BUSINESS AND SOCIAL SCIENCES

Vol. 8, No. 9, Sept. 2018, E-ISSN: 2222-6990 @ 2018 HRMARS

http://ecommons.aku.edu/pakistan_ied_pdcc

Azmanirah, A. R., Nurfirdawati, M. H., Marina, M. I., \& Jamil, A. (2014). Assessment practices for competency-based education and training in vocational college, Malaysia. Procedia - Social and Behavioral Sciences, 112(Iceepsy 2013), 1070-1076.

https://doi.org/10.1016/j.sbspro.2014.01.1271

Begum, M., \& Farooqui, S. (2008). School-based assessment : Will it really change the education scenario in Bangladesh ? International Education Studies, 1(2), 45-53. Retrieved from www.ccsenet.org/journal.html

Braun, V., \& Clarke, V. (2013). Successful qualitative research: A practical guide for beginners. London: SAGE.

Corneli, J., \& Danoff, C. J. (2011). Paragogy. In Proceedings of the 6th Open Knowledge Conference, Berlin, Germany. (pp. 1-10).

Creswell, J. W. (2008). Educational research: Planning, conducting, and evaluating quantitative and qualitative research. Upper Saddle River, NJ: Pearson/Merrill.

Czerniawski, G., \& Kidd, W. (2011). The student voice handbook: Bridging the academic/practitioner divide. Bingley: Emerald Publishing Group.

Faizah A.Majid. (2011). School-Based Assessment in Malaysian Schools : The concerns of the English teachers. US-China Education Review, 3(2), 393-402.

https://doi.org/10.14221/ajte.2015v40n2.2

Frey, B. B. (2013). Modern classroom assessment. Los Angeles: SAGE Publications.

Hasnida, N., \& Ghazali, C. M. (2016). The implementation of school-based assessment system in Malaysia: A study of teacher perceptions. GEOGRAFIA Online TM Malaysian Journal of Society and Space, 12(9), 104-117.

Hazita, A. (2012). Implementation and challenges of English language education reform in Malaysian primary schools. 3L: The Southeast Asian Journal of English Language Studies, 22(3), 65-78.

Karpudewan, M., Roth, W.-M., \& Abdullah, M. N. S. Bin. (2015). Enhancing primary school students' knowledge about global warming and environmental attitude using climate change activities. International Journal of Science Education, 37(1), 31-54.

https://doi.org/10.1080/09500693.2014.958600

Little, D. (2005). The common European framework and the European language portfolio: Involving learners and their judgements in the assessment process. Language Testing, 22(3), 321-336. https://doi.org/10.1191/0265532205/t311oa

Malakolunthu, S., \& Hoon, S. K. (2010). Teacher perspectives of school-based assessment in a secondary school in Kuala Lumpur. Procedia - Social and Behavioral Sciences, 9, 1170-1176. https://doi.org/10.1016/j.sbspro.2010.12.302

Mansor, A. N., Hee Leng, O., Sattar Rasul, M., Amnah Raof, R., \& Yusoff, N. (2013). The benefits of school-based assessment. Asian Social Science, 9(8), 101-106.

https://doi.org/10.5539/ass.v9n8p101

Ministry of Education Malaysia. (2008). Education in Malaysia: A journey to excellence. Kuala Lumpur: Educational Planning and Research Division (EPRD).

Mok, A. E. K., Nur Filza, M. Z., Nor Syazwani, M. H., \& Siti Suraya, N. (2016). Teachers' understanding of school-based assessment using the standard document for curriculum and assessment (DSKP): An exploratory study, 4(4).

Muhammad Noor, A. A., \& Nurahimah, M. Y. (2015). Using portfolio to assess rural young learners' 
INTERNATIONAL JOURNAL OF ACADEMIC RESEARCH IN BUSINESS AND SOCIAL SCIENCES

Vol. 8, No. 9, Sept. 2018, E-ISSN: 2222-6990 @ 2018 HRMARS

writing skills in English language classroom. The Malaysian Online Journal of Educational Science, 3(4), 46-54. Retrieved from http://moj-es.net/article/using-portfolio-to-assess-ruralyoung-learners-writing-skills-in-english-language-classroom

Norazilawati Abdullah; Noorzeliana Idris; Mohd Sahandri Gani Hamzah; Saniah Sembak. (2015). Planning and implementation of school-based assessment (SBA) among teachers. Procedia Social and Behavioral Sciences, 211(September), 247-254.

https://doi.org/10.1016/j.sbspro.2015.11.031

Nur Fatimah. (2014). Class performance - A Step toward an authentic assessment in teaching English to young learners, 1(1), 26-32.

Othman, N., \& Mohamad, K. A. (2014). Thinking skill education and transformational progress in Malaysia. International Education Studies, 7(4), 27-32. https://doi.org/10.5539/ies.v7n4p27

Ritchie, J., \& Lewis, J. (2003). Qualitative research practice: A guide for social science students and researchers. London: SAGE Publications.

Segers, M., \& Dochy, F. (2001). New assessment forms in problem-based learning: The value-added of the students' perspective. Studies in Higher Education, 26(3), 327-343.

Suzana, A. M., \& Jamil, A. (2012). Penggunaan teknik pentaksiran formatif dalam subjek Bahasa Melayu darjah satu: Kajian kes. Jurnal Pendidikan Bahasa Melayu, 2(1), 17-30.

Swaffield, S. (2011). Getting to the heart of authentic assessment for learning. Assessment in Education: Principles, Policy \& Practice, 18(4), 433-449. https://doi.org/10.1080/0969594X.2011.582838

Tajularipin, S., Ahmad Fauzi, M. A., \& Suriati, S. (2015). Curriculum change in English language curriculum advocates higher order thinking skills and standards-based assessments in Malaysian primary schools. Mediterranean Journal of Social Sciences, 6(2), 494-500. https://doi.org/10.5901/mjss.2015.v6n2p494

Waugh, K., \& Gronlund, N. E. (2013). Assessment of students achievement (10th ed.). New York: Pearson.

Wiggins, G. (1993). Assessing student performance: Exploring the purpose and limits of testing. San Francisco: Jossey-Bass Publishers.

Yin Peen, T., \& Yusof Arshad, M. (2014). Teacher and student questions: A case study in Malaysian secondary school problem-based learning. Asian Social Science, 10(4), 174-182. https://doi.org/10.5539/ass.v10n4p174

Yin, S. T. A., \& Adamson, B. (2015). Student voices in school-based assessment. Australian Journal of Teacher Education, 40(2), 15-28. https://doi.org/10.14221/ajte.2015v40n2.2 